\title{
13. Multiple Aboriginal placenames in western and central Victoria
}

\author{
Ian D. Clark \\ Federation University Australia
}

In a recent paper on transparency versus opacity in Australian Aboriginal placenames, Michael Walsh (2002: 47) noted that in 'Aboriginal Australia it is relatively common for a given place to have multiple names'. In providing an overview of multiple naming practices Walsh (2002: 47) stated the 'simplest case is one place having two names. Such doublets can be intralectal or crosslectal. For intralectal doublets where there are two names for the one place in the same lect, both placenames may be opaque, both transparent, or one opaque and one transparent. ... The same applies to crosslectal doublets where two names for the one place come from different lects'. Walsh (2002) observed that he was unclear on how multiple naming works and what its function is. Other than some case studies (Schebeck 2002 re Flinders Ranges, Sutton 2002 re the Wik region, Cape York, and Tamisari 2002) we are yet to gain a comprehensive picture for Aboriginal Australia. This paper adds to this discussion through a consideration of multiple naming in western and central Victoria using the results of research conducted by Clark and Heydon (2002) into Victorian Aboriginal placenames. The paper refers to examples from three languages in central and western Victoria Kulin, Wathawurrung, and Maar.

\section{Intralectal doublets}

In the study area, it has been possible to identify 20 intralectal and 12 crosslectal doublets.

Lake Buloke: Banyenong - Banye is said to mean 'burning of roots and stumps' and 'nong' 'the past' (Chauncy in Smyth 1878 Vol. 2: 205); Buluk is the descriptive Kulin word meaning swamp/lake, which suggests this may not be a placename (Hartmann in Smyth 1878 Vol. 2: 176; Blake et al. 1998: 118). Buluk is found elsewhere in Lake Buluk (Lake Bolac) and Bulukbuluk (the name of a swampy area near Mt Macedon (see Clark and Heydon 2002).

Lake Coorong: Gurrong is a common Eastern Kulin word for 'canoe' (Blake 1991: 112); the meaning of Yarrak is unknown, although it is found in the name of the local clan Yarrakaluk meaning Yarrak people (Hartmann in Smyth 1878 Vol. 
2: 176) which may favour the primacy of Yarrak. Gurrong is found elsewhere in Coorong Swamp near Rupanyup; Mount Gorong in the Moorabool Shire; and Mount Korong near Wedderburn (see Clark and Heydon 2002).

McKenzie Falls: Migunang wirab - a Jardwadjali placename meaning the blackfish cannot get any higher up' (Thornly in Smyth 1878 Vol. 2: 63); and Kurnung which means 'a hill or impediment of any kind' as well as river (Surveyor General in Smyth 1878 Vol. 2: 201; Blake 1991: 112). Wirap (blackfish) is also found in Kuwirap (Kooweerup) and Djeriwirap (Clunie) (see Clark and Heydon 2002). Kurnung is found elsewhere in Kurnung (Badger Creek) and Kurnungkurnung (Koonung Koonung Creek) (see Clark and Heydon 2002).

Mt Arapiles: Djurid - the meaning of which is unknown, however it is found in the name of the local clan - Djurid baluk (Robinson Jnl 4/4/1845); Kawa is a Kulin word meaning 'mountain, large mountain' (Hercus 1992: 23), and may not be a placename, but a descriptive word (Thornly in Smyth 1878 Vol. 2: 60; Surveyor General in Smyth 1878 Vol. 2: 199; Blake et al. 1998: 123). Kawa is seen in Mount Gowar near St Arnaud and in Kawa-panyul the name for a hill near Moonambel (see Clark and Heydon 2002).

Mt Elephant: Djerrinallum is a Wathawurrung placename meaning 'nest of sea swallows, terns' (Dawson 1881) [according to Porteous in Smyth 1878 Vol. 2: 214 this name means 'A hill of fire'], and is also the name of a local clan Djerrinallum gundidj. ${ }^{1}$ Willam/yellam is the Woiwurrung, Boonwurrung, Daungwurrung word for camp/nest (see Blake 1991); Larra is the Wathawurrung word for 'stony' (Porteous in Smyth 1878 Vol. 2: 179; Blake et al. 1998: 141), however one source identifies Larra as the name of a spring at a homestead near Mt Elephant (Surveyor General in Smyth 1878 Vol. 2: 193). ${ }^{2}$ Larra is also the name for a small township (Lara) near Geelong. It is possible then, that Larra is descriptive, or a microtoponym - referring to a nearby spring.

Mt Erip: Yirrip is the Kulin word for ironbark tree (Blake 1991: 121); the meaning of Nollo is unknown (Porteous in Smyth 1878 Vol. 2: 179). Robinson noted that this hill was 'celebrated among the natives for supplying the choice wood for their spears' (Clark 2000b: 158). Yirrip is also the name of a farming district (Yeerip) near Lake Mokoan; Yerrip Hill on Jacksons Creek in Sunbury; and an Aboriginal name for Pleasant Creek - Stawell (see Clark and Heydon 2002).

Mt Korong: Korong, Gurrong the Eastern Kulin word for 'canoe' (cf. Lake Coorong above) (Robinson Jnl 13/4/1847; Blake 1991: 112) and Burrabungale containing banyul/banhul a Kulin word meaning 'mountain' (Mitchell Jnl 5/7/1836; Blake

1 Clans are likely to be named after the locations.

2 There are two separate nouns in some Kulin languages - lar (with a dot under the r) 'camp, nest, home' and lar 'stone'. 
1991: 106). Banyul is found elsewhere in Banyule Flats Reserve in Heidelberg; Lianganuk banhul (Mount Alexander); Bergerer panhul (an unidentified hill near Mitchellstown); Kawa-panyul (see above discussion for Mt Arapiles); and Pillawin-panyul (The Pyrenees) (see Clark and Heydon 2002).

Mt Macedon: Geboor (Mitchell Jnl 30/9/1836, confirmed by Robinson in Clark 2000b: 219) and Tarehewait (Robinson Jnl 21/1/1840).

Mt Napier: Murroa (first recorded by Mitchell Jnl 10/9/1836 and later confirmed by Robinson 1841) and Taapuuk, meaning unknown, however, the local clan was named Taapuuk gundidj (Robinson Jnl 5/5/1841) which would seem to give primacy to the latter name.

Mt Poolongoork: Bula(ng)goork meaning 'the two women' and Mecornam, meaning unknown (Porteous in Smyth 1878 Vol. 2: 179).

Murchison: Boolumbel, meaning unknown (Horsburgh 1850 in Clark 1999: 58) and

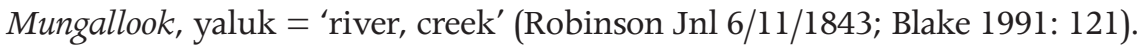

Stockyard Hill: Bapel meaning 'fat' (Porteous in Smyth 1878 Vol. 2: 179), similar to bepul identified by Hercus (1986: 199) as the Djadjala (dialect of Wergaia) word for fat, also kidney-fat; and Powerwil, presumably a reference to Barwal, the Kulin word for 'island' (Robinson in Clark 2000b: 152; Blake 1991: 107). Barwal is seen elsewhere in reference to French Island and Swan Island (see Clark and Heydon 2002). A swamp at Tyntynder near Swan Hill is also known as Bapel (see Clark and Heydon 2002).

Swan Hill: Barbariook meaning unknown (Massola 1968: 46) and Merterrukpert, 'platypus' (Gummow in Smyth 1878 Vol. 2: 176). There is also a crosslectal Wanilu which is what people said in more recent days (Hercus, pers. comm. 25 June 2013).

Swan Island: Barwal (Morgan 1967: 7), the generic Kulin word for 'island' (Blake 1991: 107) (see discussion for Stockyard Hill); and Woorang-a'look which 'describes the rushing sounds of the surf through the narrow opening between the island and the mainland' (Lang 1865 in Smyth 1878 Vol. 2: 217). Blake and others (1998: 134) confirm that warri is the Wathawurrung word for sea, and warriyn is the adjoining Woiwurrung word.

Condah Swamp: Konda is the Dhauwurdwurrung word for 'water' (Dawson 1881; Mathew Papers 1907; Krishna-Pillay 1996: 214); Tyarrk refers to the common reed Phragmites australis (Dawson 1881; Krishna-Pillay 1996: 196; Blake 2003: 139). Krishna-Pillay considers 'quondum' is equivalent to 'parreeyt' meaning 'water'. There are many instances of Tyarrk elsewhere in Victoria, including 
Langanong-djark the endonym for Ashens (Wilson in Smyth 1878 Vol. 2: 177); ${ }^{3}$ Tjarrk the endonyms for Framlingham (Lane in Smyth 1878 Vol. 2: 187); Kelly Swamp (Robinson in Clark 2000b: 100); a swamp on Koort Koort Nong pastoral run (Scott in Smyth 1878 Vol. 2: 185); a swamp near Larra homestead (Dawson 1881: lxxxii); Olinda Creek (Robinson Jnl 30/8/1840); a creek near Mt Campbell (Robinson Jnl 27/5/1840); and finally the Melbourne suburb of Toorak.

Griffiths Island: Mallin (Robinson Jnl 28/4/1841) meaning 'island' and confirmed in the name of the local group Mallingundidj (Blake 2003: 109); and Meerring (Robinson Jnl 27/8/1841) meaning 'eye, hole in the ground' (Krishna-Pillay 1996). Mallin is found elsewhere in Kurnnamaleen, 'little islands' on the west side of Lady Bay near the mouth of the Merri River (see Dawson 1881: lxxx), and Kurtbaulen 'islands of stone', a descriptive name for the Stony Rises (see Scott in Smyth 1878 Vol. 2: 182). Meerring is seen elsewhere in Martung-mirring 'big eye', the name of a marsh in the vicinity of Lake Purrumbete (Scott in Smyth 1878 Vol. 2: 182); and Yatt mirng 'white eye', the name for a sink hole at Mount Rouse (Dawson 1881: lxxxiv) and a crater in Tower Hill Island (Dawson 1881: lxxxiv).

Lake Gnotuk: Ngutuk-killingk the Marr word 'my/your lake' (Lane in Smyth 1878 Vol. 2: 187; Krishna-Pillay 1996: 179) and Yammercurrermudjoke, of unknown meaning (Robinson in Clark 2000b: 88). Killingk is found in at least another 12 placenames including Korangamitj killingk; Kunawarr killingk; Yelingamadj killingk; Kilambidj killingk; Pertobe killingk; and Yambuk killingk.

Lady Julia Percy Island: Din mar 'this blackfellow here' (Dawson 1881: lxxix; Krishna-Pillay 1996: 193) and Tirngoona 'where the sun go away longa night' (Port Fairy Gazette, 26 August 1902; Krishna-Pillay 1996: 207).

Mt Eckersley: Kang-beem-beem meaning 'hill/mountain-head' (Robinson Jnl 27/5/1841; Krishna Pillay 1996: 174, 175, 186; Blake 2003: 104, 106) and Yiyar, also found in the local clan named Yiyar gundidj (Robinson Jnl 25/6/1841). Beem is found elsewhere in Butj-peem (Mt Eccles) (Lane in Smyth 1878 Vol. 2: 187); and Kartbimyoke 'large head' the name of an unidentified hill near Heywood (Robinson Jnl 28/5/1841). Kang is seen in Pinnambul kang (Mt Clay) (Robinson Jnl 18/5/1841); Wukrnnumbol caark (Mt Garvoc) (Lane in Smyth 1878 Vol. 2: 187); Karngeeyang (Keayang Home Station south of Terang) (Lane in Smyth 1878 Vol. 2: 187); and Lehurra kang (Mt Leura) (Lane in Smyth 1878 Vol. 2: 187).

3 Endogenous names are those given by an ethnic group to features in their own language area; exogenous names are those given to these features by external ethnic groups. 


\section{Crosslectal doublets}

In the case of these crosslectal doublets seven are mountains, two are lakes, one is a promontory, and two are localities. In the case of the mountains and the promontory these features are clearly observable from the vantage point of the adjoining lect. The locality Hexham and the two lakes are on the margins of the lects concerned.

Franklinford: this placename falls within the Djadjawurrung dialect area. Larng-i-barriamul and Willam-i-barriamul both mean nest/camp/home (lar(ng)/ willam) of the emu (barriamul) (Robinson Jnl 19/11/1841, Surveyor General in Smyth 1878 Vol. 2: 195, Blake 1991: 106; Hercus 1986: 207; 1999), however Larng-i-barriamul is endogenous and Willam-i-barriamul is exogenous. Willam is the Woiwurrung, Boonwurrung, and Daungwurrung word for camp/nest (see Blake 1991) and is found elsewhere in Willam-i-murring 'tomahawkhouse' (Mount William Quarry near Lancefield) and Willam-wyn (camp/hut fire) (Pentland Hills) (see Clark and Heydon 2002). Lar is the Djadjawurrung, Djabwurrung, Wembawemaba, Djadjala, and Wathawurrung equivalent (see Hercus 1986) (q.v. discussion regarding Mt Elephant, above) and there are many examples of its usage including Larngikurrurk 'home of the magpie' (Cardinal Hill); Larngidorn 'nest of the bell-bird' (Doctors Creek); Larngiguragurg 'home of female kangaroos' (Mount Hollowback); Larngigure 'home of kangaroo' (Laanecoorie Reservoir); Larngikalkal 'dogs camp' and/or 'resting place of cicada'; Larngiyin 'camp of the moon' (Mount Misery); and Larnuk containing the possessive marker -uk 'his/her/its camp' (Mount Widderin Cave) (see Clark and Heydon 2002).

Hexham: Bulla-bulla, the Djabwurrung word meaning 'good' (Lane in Smyth 1878 Vol. 2: 187), and Petereet, the Dhauwurdwurrung name for the masked lapwing (formerly called spurwinged plover) (Goodall in Smyth 1878 Vol. 2: 187; Dawson 1881; Krishna-Pillay 1996: 179; Blake 2003: 135).

Mt Emu: known to local Wathawurrung people as Tarecurrumbeet (Robinson Jnl 5/8/1841), and to the Marr people as Narrowhane (Goodall in Smyth 1878 Vol. 2: 187).

Mt Langi Ghiran: Larngidjerin 'home of the black cockatoo' (Robinson Jnl 10/7/1841), the local Djabwurrung name; but neighbouring Wathawurrung named the feature Corrong-ah-jeering 'house/camp of cockatoo' (Tyers 1840 in Smyth 1878 Vol. 2: 216; Blake 1991: 112; Blake et al. 1998). Charles Tyers recorded the Wathawurrung name as referring to Mt Cole, which adjoins Mt Langi Ghiran, however its similarity with Langi Ghiran suggests he has misunderstood his source. According to Dawson (1881) the local Djabwurrung word for black cockatoo was 'wiran', a reference to the Banksian cockatoo (or 
red tailed black cockatoo; Calyptorhynchus magnificus). Chauncy (1862-66 in Smyth 1878), notes that 'gherin' is a reference to the yellow-tailed black cockatoo (funereal cockatoo; Calyptorhyncus funereus); however in support of Dawson, Blake and others 1998: 101 note that djerrin is 'black cockatoo with red'.

Mt Sturgeon: Wurgarri meaning 'black' is the local Djabwurrung name for this feature (Robinson Jnl 26/6/1841; Hercus 1986: 254), the local clan was named Wurgarri gundidj; the Giraiwurrung knew the feature as Tolelokewearr (Robinson Jnl 5/5/1841). Malubgar is a second Djabwurrung name recorded in the literature, meaning 'that mountain there' and is probably not a placename (Robinson Papers in Clark 2000b: 135).

Mt William: Duwul the local Djabwurrung language name meaning 'The Mountain' (Robinson Jnl 3/8/1841) - the local clan was known as Duwul baluk; Worranneyan, is recorded as the Giraiwurrung name for this mountain (Robinson Jnl 13/7/1841).

The Pyrenees: known by the local Djadjawurrung as Pilliwin-panyul, containing 'bili' 'stomach', panyul = hill (Robinson Jnl 27/2/1840; Blake 1991: 106), and seen in the local group name 'Pilliwin baluk' and to the adjoining Wathawurrung as Peerick (Tyers 1840 in Smyth 1878 Vol. 2: 216), possibly a reference to beerik, native cat (Surveyor General in Smyth 1878 Vol. 2: 199).

Wilsons Promontory: known to the eastern Kulin as Wammun (Robinson Jnl 27/4/1844) and western Ganai as Yiruk (Massola 1968: 53).

Lake Colac: Kulak, the Gulidjan word for 'sand' (Dawson 1881: lxxx; KrishnaPillay 1996: 198); the Wathawurrung knew the lake as Koram (Porteous in Smyth 1878 Vol. 2: 179; Surveyor General in Smyth 1878 Vol. 2: 193).

Lake Gnarpurt: Ngarpurt a Marr placename of unknown meaning (Porteous in Smyth 1878 Vol. 2: 179) and Kongiadigallock, an exogenous Wathawurrung placename possibly containing yaluk the Kulin word for 'creek/river' (Morgan 1967: 36; Blake et al. 1998: 133).

Mt Kerangemoorah: known to the local Gulidjan as Korrangermurrer (Robinson Journal 27/3/1841) and as Worayan to their Wathawurrung neighbours (Porteous in Smyth 1878 Vol. 2: 179).

Mt Shadwell: Boorook or Boorook kang, a Giraiwurrung toponym meaning 'head mountain' (Robinson Jnl 4/4/1841; Scott in Smyth 1878 Vol. 2: 181; Goodall in Smyth 1878 Vol. 2: 187) [translated as 'a cold in the head' (Porteous in Smyth 1878 Vol. 2: 214)], and the local clan was named Boorook gundidj; and Dooroobdoorabal was the Wathawurrung name for this feature (Tyers 1840 in Smyth 1878 Vol. 2: 216). 


\section{Intralectal triplets}

Michael Walsh (2002: 48) noted that some places have more than two names. In the study area it has been possible to identify nine toponymic triplets - six intralectal and three crosslectal.

Arthurs Seat: three Boonwurrung (Kulin) names have been recorded for this feature: Momo, Tubberrubberbil (Robinson Jnl 28/7/1840) and Wonga. Tubberrubberbil is possibly confused with Tubba Rubba Creek. Thomas (in Smyth 1878 Vol. 1: 55) noted that Wonga, a Woiwurrung clan head 'was born at Wonga (Arthur's Seat) and thus has the name'. Blake (1991: 96) noted that the adjective 'some' was 'wonga' in eastern Kulin.

French Island: Bellarmarin (Thomas 1840 map), Bawal (Haydon in Gooch 2006: 20; Blake 1991: 92), the descriptive Kulin word for 'island', Woone (Smyth field book in Gooch 2006: 272) and Jouap (Thomas 1841 map) (but Haydon gives the name of a lagoon on the island as Tooaiup (Gooch 2006: 272). O'Callaghan (1918: 92) has suggested that 'Tyaba' means 'worm'. ${ }^{4}$ Jouap survives today as Tyabb, a township on Western Port Bay, not too distant from French Island.

Victoria Range: three names have been recorded for the Victoria Range: Billiwin, containing 'bili' 'stomach' (Surveyor General in Smyth 1878 Vol. 2: 202), after which the local clan Billiwin balug was named (Clark and Harradine 1990: 51), Bareng meaning 'river' (Surveyor's Returns, 1869-70; Surveyor General in Smyth 1878 Vol. 2: 199), and Larneyannun, containing 'lar(ng)i' 'the nest/camp of ...' (Robinson in Clark 2000b: 150)

Lake Condah: there are three names in the primary sources for this lake - all within the Marr language - Koondoom meaning 'water' (Mathew Papers 1907; Krishna-Pillay 1996: 214; Blake 2003: 169); Karrap meaning 'lake' (Lane in Smyth 1878 Vol. 2: 187); and Tyarrk, a reference to the common reed Phragmites australis (Dawson 1881: lxxxxii; Krishna-Pillay 1996: 196) (q.v. discussion regarding Condah Swamp, above). Gundidj meaning 'belonging to' (Stahle 1880 in Howitt Papers) is a fourth name recorded for this topographical feature however this is unlikely to be a placename and Clark (1990) has argued that Stahle has misunderstood his Aboriginal sources.

Mt Pierrepoint: Allowween (Robinson Jnl 1/7/1841), Culmurri (Robinson in Clark 2000b: 129), and Parreeyt, a Marr word meaning 'water' (Robinson Jnl 13/11/1843; Dawson 1881; Krishna-Pillay 1996: 214; Blake 2003: 169). Parreeyt

4 Hercus (pers. comm. 13 June 2013) has suggested that it is possible that $\mathrm{O}^{\prime}$ Callaghan may have been thinking of the Arrernte tyape 'grub'. 
is seen elsewhere, for example, 'Mumpareeyt' 'bottom of the water' (Spring Creek, near Mt Rouse); and 'Lapeeyt parreeyt' 'salt water' (a locality on the Hopkins River) (see Clark and Heydon 2002).

Port Fairy: Puyupkil, a reference to Mesembryanthemum or pig face, and the name of the local clan Puyupkil gundidj (Robinson in Clark 2001b: 18; KrishnaPillay 1996: 193), Tarngunnet (Robinson in Clark 2000b) a placename similar to that recorded for Lady Julia Percy Island (Tirngoona, see above) which was translated as 'where the sun go away longa night'; and Nyamat meaning 'sea, ocean, sea water, wave' (Robinson Jnl 28/4/1841; Lane in Smyth 1878 Vol. 2: 187; Krishna-Pillay 1996: 198; Blake 2003: 198).

\section{Crosslectal triplets}

Mt Ida: Borebine [Daungwurrung] (Robinson Jnl 27/5/1840); Dayderric [Daungwurrung] (Robinson Jnl 27/5/1840); Dyerndemal [Djadjawurrung] (Robinson Jnl 29/11/1842).

The Grampians: Gariwerd, the Jardwadjali/Djabwurrung name for the mountain range meaning 'The Mountain Range' (Robinson Jnl 11/6/1841; Clark and Harradine 1990: 44); Murraibuggum, containing marree meaning 'stone', the Dhauwurdwurrung name (Tyers 1842 in Smyth 1878 Vol. 2: 66; Krishna-Pillay 1996: 206; Blake 2003: 192); and Tolotmutgo, the Wathawurrung name for these mountains (Tyers diary 26/2/1840). In addition to these three names, there are two other attributions found in the literature: Duwul, a Kulin word meaning mountain, that also refers specifically to Mt William (Dawson 1881: lxxxii); and Kawa, a Kulin generic word meaning 'abrupt mountains' and probably a descriptive word and not a placename (Wilson in Smyth 1878 Vol. 2: 178; Blake et al. 1998: 123).

Mt Gellibrand: Worcanweluc, the local Gulidjan name (Robinson Jnl 25/3/1841); and Loo-larrung-oo-lak, its Wathawurrung name, recorded by Tyers (Jnl 19/10/1839; also see Tyers 1840 in Smyth 1878 Vol. 2: 216). Robinson (Jnl 13/11/1843) recorded a third name for Mt Gellibrand, Nolarric, however, its language of origin is unknown.

\section{Conclusion}

This study has found 19 possible intralectal doublets in the study area. Of these, perhaps nine may be based on errors in that descriptive words have been mistaken as placenames, for example, buluk the generic Kulin word for lake, 
kawa the generic Kulin word for mountain/large mountain, barwal the Kulin word for island and mallin, the Marr equivalent. Others may be examples of confusion between names of the primary feature, such as a mountain, and a microtoponym of a feature near the mountain, such as a spring - this was the case at Djerrinallum. Other examples suggest a misunderstanding between the Aboriginal source and the recorder - such as Ngutuk-killingk which means 'my/your lake'. The situation regarding intralectal doublets was similar with intralectal triplets - it was difficult to find examples where all three names had integrity - many were confusions between generic words for features such as islands, rivers, water, lake, and sea. In the case of cross-lectal placenames, the situation has greater clarity and all 12 examples studied here are considered to have integrity. In two cases both crosslectal names have the same meaning Larng-i-barriamul and Willam-i-barriamul both mean 'nest/camp/home of the emu' and Larng-i-djerin and Corrong-ah-jeering both mean 'nest/camp/home of red tailed black cockatoo'. Similarly with crosslectal triplets all three examples were considered to have integrity. This study has not been able to show how multiple naming worked, nor its function, but it nevertheless has added to the ongoing discussion by providing some understanding of the situation in western Victoria.

\section{References}

Blake, B.J. 1991, 'Woiwurrung, the Melbourne Language', in The Handbook of Australian Languages, Vol. 4 The Aboriginal Language of Melbourne and other Grammatical Sketches, R.M.W. Dixon and B.J. Blake (eds), Oxford University Press, South Melbourne: 31-124.

- 2003, The Warrnambool Language - A Consolidated Account of the Aboriginal Language of the Warrnambool Area of the Western District of Victoria based on nineteenth-century sources, Pacific Linguistics, Research School of Pacific and Asian Studies, The Australian National University, Canberra.

Blake, B.J., I.D. Clark and S.H. Krishna-Pillay 1998, 'Wathawurrung: the language of the Geelong-Ballarat area', in Wathawurrung and the Colac Language of Southern Victoria, B.J. Blake (ed), Pacific Linguistics, Series C, Vol. 147, Research School of Pacific and Asian Studies, The Australian National University, Canberra: 59-154.

Clark, I.D. 1990, Aboriginal Languages and Clans, an Historical Atlas of Western and Central Victoria, 1800-1900, Monash Publications in Geography, No. 34, Department of Geography, Monash University, Clayton. 
Indigenous and Minority Placenames

- 1999, A History of the Goulburn River Protectorate Station at Murchison, 1840 1853, A Report to the Heritage Services Branch, Aboriginal Affairs, July.

Clark, I.D. (ed.) 2000a, The Journals of George Augustus Robinson, Chief Protector, Port Phillip Aboriginal Protectorate, Volumes 1-6, Heritage Matters, Clarendon [Cited as Robinson Jnl].

- 2000b, The Papers of George Augustus Robinson, Chief Protector, Port Phillip Aboriginal Protectorate, Volume 2, Heritage Matters, Clarendon.

Clark, I.D. and L.L. Harradine 1990, The Restoration of Jardwadjali and Djabwurrung Names for Rock Art Sites and Landscape Features in and around the Grampians National Park, A submission to the Place Names Committee on behalf of Brambuk Inc. and the Koorie Tourism Unit, Victorian Tourism Commission, Melbourne.

Clark, I.D. and T.G. Heydon 2002, Dictionary of Aboriginal Placenames of Victoria, Victorian Aboriginal Corporation for Languages, Melbourne.

Dawson, J. 1881, Australian Aborigines; the languages and customs of several tribes of Aborigines in the Western District of Victoria, Robertson, Melbourne.

Gooch, R. 2006, Frontier French Island, Prahran Mechanics Institute Press, Prahran.

Hercus, L.A. 1986, Victorian Languages: A Late Survey, Pacific Linguistics Series B-No. 77, Department of Linguistics, Research School of Pacific Studies, The Australian National University, Canberra.

- 1992, Wembawemba Dictionary, The Author, Canberra.

Howitt, A.W. Papers, State Library of Victoria, Ms. 9356.

Krishna-Pillay, S.H. (ed.) 1996, A Dictionary of Keerraywoorroong and Related Dialect, Gundidjmara Aboriginal Cooperative, Warrnambool.

Massola, A.S. 1968, Aboriginal Placenames of South-east Australia and their Meanings, Lansdowne Press, Melbourne.

Mathew, J. Papers, Australian Institute of Aboriginal and Torres Strait Islander Studies, Canberra, Ms. 950.

Mitchell, T.L. 1996, Three Expeditions into the interior of Eastern Australia with the Descriptions of the Recently Explored Region of Australia Felix, and of the Present Colony of New South Wales, 2 Vols, Brian A. Kelly, Maryborough [first published 1839] [cited as Mitchell jnl]. 
Morgan, J. 1967, The Life and Adventures of William Buckley Thirty-two years a wanderer amongst the Aborigines of the then unexplored country around Port Phillip, now the province of Victoria, Heinemann, London [First published 1857].

O'Callaghan, T. 1918, Names of Victorian Railway Stations with their origins and meanings, together with similar information relative to the Capital Cities of Adelaide, Sydney, Brisbane and a few of the Border Stations of New South Wales and South Australia, HJ Green, Acting Government Printer, Melbourne.

Schebeck, B. 2002, 'Some remarks on placenames in the Flinders', in The Land is a Map: Placenames of Indigenous Origin in Australia, L. Hercus, F. Hodges, and J. Simpson (eds), Pandanus Books in association with Pacific Linguistics, Canberra: 140-156.

Smyth, R.B. 1878, The Aborigines of Victoria: with notes relating to the habits of the natives of other parts of Australia and Tasmania, 2 Volumes, Victorian Government Printer, Melbourne.

Surveyor's Returns 1869-70, Surveyor General Inward Correspondence, Miscellaneous Surveyors' Returns 1869-70, Department of Natural Resources and Environment, Melbourne, 1 folder [Copy is held by the Victorian Aboriginal Corporation for Languages, Melbourne].

Sutton, P. 2002, 'On the translatability of placenames in the Wik region, Cape York Peninsula', in The Land is a Map: Placenames of Indigenous Origin in Australia, L. Hercus, F. Hodges, and J. Simpson (eds), Pandanus Books in association with Pacific Linguistics, Canberra: 75-86.

Tamisari, F. 2002, 'Names and Naming - speaking forms into place', in The Land is a Map: Placenames of Indigenous Origin in Australia, L. Hercus, F. Hodges, and J. Simpson (eds), Pandanus Books in association with Pacific Linguistics, Canberra: 87-102.

Thomas, W. 1840 map of Western Port [reproduced in Moorhead, L.M. 1971, Mornington in the wake of Flinders, Shire of Mornington, Mornington].

Thomas 1841 map in Thomas, W. Papers, Sixteen volumes and eight boxes of papers, journals, letterbooks, reports, correspondence, etc, Mitchell Library, Sydney, uncatalogued Mss, Set 214, Items 1-24.

Tyers, C.J. Diaries and Letterbooks, La Trobe Library, Melbourne, Ms. 8151.

Walsh, M. 2002, 'Transparency versus opacity in Aboriginal placenames', in The Land is a Map: Placenames of Indigenous Origin in Australia, L. Hercus, F. Hodges, and J. Simpson (eds), Pandanus Books in association with Pacific Linguistics, Canberra: 43-49. 
This text taken from Indigenous and Minority Placenames: Australian and International Perspectives, Edited by Ian D. Clark, Luise Hercus and Laura Kostanski, published 2014 by ANU Press, The Australian National University, Canberra, Australia. 